Jurnal Ekonomi Syariah Darussalam

Vol I No I Agustus 2020, ISSN: 2745-8407

\title{
PENGARUH LOKASI DAN KUALITAS PELAYANAN ISLAMI TERHADAP KEPUTUSAN PEMBELIAN KONSUMEN DI UNIT TOKO AUSATH GROSIR SEMBAKO KOPPONTREN AUSATH BLOKAGUNG
}

\author{
Ribut Suprapto ${ }^{1}$, Durrotun Nafisah ${ }^{2}$ \\ Institut Agama Islam Darussalam Blokagung Banyuwangi \\ Email: ributsuprapto9@gmail.com¹,Nafisah.dn11@gmail.com²
}

\begin{abstract}
The purpose of this study is 1) To determine the significant effect between location (X1) on purchasing decisions (Y). 2) To determine the significant influence of the quality of Islamic services on purchasing decisions (X2). 3) To find out the significant influence between location (X1) and the quality of Islamic services (X2) simultaneously or together on purchasing decisions (Y). The results of the multiple regression test obtained the coefficient price $\left(r_{x 1 \times 2 y}\right)$ of 0.701 and the price of the coefficient of determination $\left(r_{x 1 x 2 y}\right)^{2}$ of $49.140 \%$. The $F\left(r_{x 1 x 2 y}\right)$ test results showed that the $F_{\text {hitung }}$ was 13.046 and the $F_{\text {tabel }}$ at the $5 \%$ level was 3.35. T test results are known that thitung shows that the figure is greater than $t_{\text {tabel }}$ or 13,046>3.35 so that there is a significant influence between the location and quality of Islamic services simultaneously on consumer purchasing decisions in Ausath Grocery Grocery Unit Unit at Ausath Blokagung Banyuwangi Regency. This means that each independent variable, namely location and quality of Islamic services, has a significant simultaneous effect on the dependent variable (consumer purchase decision) in the Ausath Grocery Store Unit of Ausath Blokagung Koppontren, Banyuwangi.
\end{abstract}

\section{Keywords: Location, Quality of Islamic Services, Purchasing Decisions}

\begin{abstract}
Abstrak
Tujuan penelitian ini adalah 1) Untuk mengetahui pengaruh signifikan antara lokasi (X1) terhadap keputusan pembelian (Y). 2) Untuk mengetahui pengaruh signifikan kualitas pelayanan Islami terhadap keputusan pembelian (X2). 3) Untuk mengetahui pengaruh signifikan antara lokasi (XI) dan kualitas pelayanan Islami (X2) secara simultan atau bersama-sama terhadap keputusan pembelian (Y). Hasil dari uji regresi berganda diperoleh harga koefisien $\left(r_{x I x z y}\right)$ sebesar 0,701 dan harga koefisien determinasi $\left(r_{x 1 x 2 y}\right)^{2}$ sebesar 49,140\%. Hasil uji $F\left(r_{x 1 x 2 y}\right)$

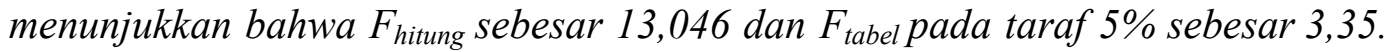
Hasil uji t diketahui bahwa thitung menunjukan bahwa angka lebih besar dari pada $t_{\text {tabel }}$ atau 13,046 > 3,35 sehingga terdapat pengaruh signifikan antara lokasi dan kualitas pelayanan Islami secara simultan terhadap keputusan pembelian konsumen di Unit Toko Ausath Grosir Sembako Koppontren Ausath Blokagung Kabupaten Banyuwangi. Artinya masing-masing variabel bebas yakni variabel lokasi dan kualitas pelayanan Islami berpengaruh signifikan secara simultan terhadap variabel terikat (keputusan pembelian konsumen) di Unit Toko Ausath Grosir Sembako Koppontren Ausath Blokagung Kabupaten Banyuwangi.
\end{abstract}

Kata Kunci: Lokasi, Kualitas Pelayanan Islami, Keputusan Pembelian 
Jurnal Ekonomi Syariah Darussalam

Vol I No I Agustus 2020, ISSN: 2745-8407

\section{A. PENDAHULUAN}

Perkembangan dunia bisnis kini semakin dinamis seiring dengan semakin meningkatnya permintaan masyarakat terhadap produk dan jasa untuk memenuhi segala kebutuhannya. Demi menjaga kelangsungan usaha di tengah-tengah persaingan bisnis yang sangat kompetitif, suatu perusahaan atau toko harus memberikan kepuasan terhadap pelanggannya.

Lokasi yang strategis dan kualitas pelayanan Islami yang baik dan terjangkau mempengaruhi keputusan pembelian konsumen. Penelitian ini memilih tempat untuk melakukan penelitian yakni di Unit Toko Ausath Grosir Sembako (Sembilan bahan pokok), dikarenakan Unit Toko Ausath Grosir Sembako ini yang diketuai oleh bapak Hamam Ikhsan dan dengan dibantu oleh beberapa stafnya ini merupakan toko yang didalamnya menyediakan berbagai macam kebutuhan pokok yang sangat dibutuhkan oleh konsumen dalam setiap harinya. Unit Toko Ausath Grosir Sembako ini adalah toko yang berada dibawah naungan cabang Koppontren Ausath (Koperasi Pondok Pesantren Atas Usaha Thullab), yang didirikan langsung oleh salah satu dari Pengasuh Pondok Pesantren Darussalam yakni, KH. Ahmad Munib Syafa'at dan juga yang dibantu dengan beberapa pengasuh lainnya. Koppontren Ausath (Koperasi Pondok Pesantren Atas Usaha Thullab) ini beroperasi untuk menyalurkan dana untuk dikelola menjadi sebuah usaha bisnis yang membuahkan hasil keuntungan yang besar, dengan membuka beberapa cabang unit usaha diantaranya yaitu: Unit Toko Santri, Unit Kantin, Unit Fotografi Dan Aksesoris, Unit Warnet Computer, Unit ATK. Net, Unit Konveksi, Usaha Simpan Pinjam Pola Syariah, Unit Usaha Toko Bangunan, Unit Usaha Minimarket, dan salah satunya juga yaitu Unit Toko Grosir Sembako ini (Profil Koppontren AUSATH Blokagung Banyuwangi, 2019:7).

Pengaruh lokasi dan kualitas pelayanan Islami seringkali digunakan sebagai indikator nilai bilamana lokasi dan pelayanan Islami tersebut dihubungkan dengan keputusan pembelian konsumen atas suatu barang yang akan dibeli oleh konsumen. Pengaruh lokasi yang strategis sangatlah berpengaruh terhadap keputusan pembelian karena lokasi yang tidak tepat dan tidak strategis, maka semakin sedikitnya pelanggan yang akan membeli produk yang dijual. Selain itu, banyak sekali yang berhubungan dengan pelayanan Islami yang melatarbelakangi pembeli 
Jurnal Ekonomi Syariah Darussalam

Vol I No I Agustus 2020, ISSN: 2745-8407

memilih antara meneruskan membeli suatu produk atau berhenti untuk membeli, karena pelayanan Islami yang tidak optimal sangat berpengaruh terhadap sebuah nilai keputusan pembelian konsumen dalam membeli. Tindakan konsumen tersebut akan sangat berpengaruh terhadap suatu proses pengambilan keputusan mengenai suatu pembelian, proses ini adalah proses pendekatan dimana guna untuk melakukan penyesuaian terhadap pembelian (Kotler, 2004:224).

Konsep Islam juga mengajarkan kita supaya memberikan tindakan pelayanan Islami yang sangat baik dari usaha yang dijalankan, baik berupa barang maupun berupa jasa. Jangan memberikan pelayanan yang buruk ataupun yang tidak berkualitas dan tidak bermutu, aka tetapi berikanlah pelayanan Islami yang terbaik kepada semua orang, khususnya bagi para pelanggan dalam hukum jual beli atau berdagang. Hal tersebut yang termaktub dalam salah satu ayat Al-Quran yakni Surat Al-Baqarah ayat 267.

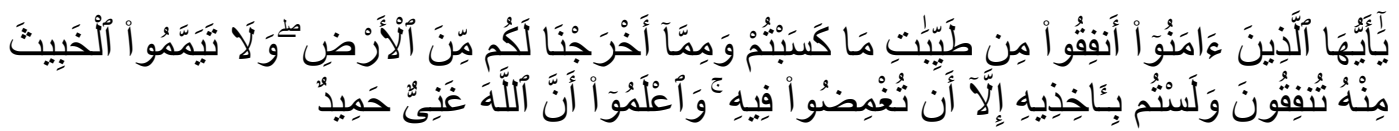

Artinya: "Hai orang-orang yang beriman, nafkahkanlah (di jalan allah) sebagian dari hasil usahamu yang baik-baik dan sebagian dari apa yang Kami keluarkan dari bumi untuk kamu. Dan janganlah kamu memilih yang buruk-buruk lalu kamu menafkahkan daripadanya, padahal kamu sendiri tidak mau mengambilnya melainkan dengan memincingkan mata terhadapnya. Dan ketahuilah, bahwa Allah Maha Kaya lagi Maha Terpuji” (Al-Baqarah Ayat 267).

Perkembangan yang terjadi, tingkat pendidikan masyarakat meningkat begitu juga pola berfikir masyarakat lebih modern, dan juga diikuti dengan kesadaran pentingnya kualitas pelayanan Islami. Unit Toko Grosir Sembako cabang Koppontren AUSATH ini perlu membuat sebuah strategi yang tepat agar terus dapat bertahan menjadi toko yang dipercaya oleh masyarakat sekitar, dalam hal mempertahankan kualitas pelayanan Islami yang baik. Kesulitan yang dihadapi bagaimana mempertahankan sebuah kepercayaan dimata konsumen dan masyarakat luas terhadap Unit Toko Grosir Sembako, dengan melalui lokasi yang strategis serta mempertahankan kualitas kelayakan dalam hal pelayanan Islami yang nyaman, agar mereka tetap bertahan dan betah datang ke Unit Toko Grosir Sembako untuk kembali membeli produk atau barang yang dijual, sehingga mereka para konsumen menetapkan sebuah keputusan pembelian di Unit Toko Grosir 
Jurnal Ekonomi Syariah Darussalam

Vol I No I Agustus 2020, ISSN: 2745-8407

Sembako dan menjadi pelanggan tetap di Unit Toko Grosir Sembako ini, dari pihak

Unit Toko Grosir Sembako perlu bertahan mempertahankan sebuah kepercayaan dari konsumen dengan memberikan kualitas yang baik dalam hal pelayanan Islami dan lokasi aman dan nyaman untuk konsumen agar berpengaruh terhadap keputusan pembelian konsumen yang hendak membeli, sehingga keputusan pembelian konsumen untuk memutuskan menjadi pelanggan di Unit Toko Grosir Sembako tetap terjaga.

Memahami dan mempertimbangkan masalah lokasi dan kualitas pelayanan Islami sangatlah penting bagi pihak wirausahawan pemilik usaha Unit Toko Grosir Sembako. Mencermati kondisi fenomena tersebut, khususnya yang terjadi pada Unit Toko Grosir Sembako cabang Koppontren AUSATH Blokagung, maka Rumusan Masalah dalam penelitian ini adalah: 1) Adakah pengaruh antara lokasi (X1) terhadap keputusan pembelian konsumen (Y) di Unit Toko Ausath Grosir Sembako Cabang Koppontren Ausath Dusun Blokagung Desa Tegalsari Kabupaten Banyuwangi?,2) Adakah pengaruh antara kualitas pelayanan islami (X2) terhadap keputusan pembelian konsumen (Y) di Unit Toko Ausath Grosir Sembako Cabang Koppontren Ausath Dusun Blokagung Desa Tegalsari Kabupaten Banyuwangi?, 3) Adakah pengaruh antara lokasi (X1) dan kualitas pelayanan islami (X2) secara simultan atau bersama-sama terhadap keputusan pembelian konsumen (Y) di Unit Toko Ausath Grosir Sembako Cabang Koppontren Ausath Dusun Blokagung Desa Tegalsari Kabupaten Banyuwangi?

\section{B. LANDASAN TEORI}

\section{Tinjauan tentang Manajemen Pemasaran}

Manajemen adalah unsur yang rangkaiannya dibuat untuk menggerakan para pegawai dan mengarahkan semua fasilitas kerja supaya tujuan dapat tercapai. Pemasaran menurut berpendapat bahwa: Pemasaran menyangkut perencanaan secara efisien terhadap konsumen, sumber-sumber dan pendistribusian barang atau jasa dari produsen ke konsumen (Marwan, 2001:13).

\section{Tinjauan tentang Lokasi}

Pemilihan lokasi yang strategis adalah strategi pemasaran yang dianggap penting guna untuk dijadikan sebuah acuan dalam menentukan tercapainya sebuah tujuan dari setiap perusahaan. Lokasi (place) ialah sebuah bauran pemasaran pada 
Jurnal Ekonomi Syariah Darussalam

Vol I No I Agustus 2020, ISSN: 2745-8407

urutan nomor tiga yakni, sesudah produk dan harga. Lokasi yaitu suatu tempat di mana sebuah perusahaan melakukan kegiatan fisik, yang memiliki fungsi strategis. Salah satu kunci sukses yang sangat penting bagi para pelaku bisnis usaha ekonomi ialah lokasi. Lokasi (place) menunjukkan bermacam-macam kegiatan yang dilakukan sebuah perusahaan maupun toko usaha untuk menjadikan barang maupun produknya bisa untuk diperoleh dan juga tersedia untuk konsumen. Faktor-faktor dalam pemilihan lokasi adalah (Wahjono, 2010:126):

1. Lingkungan Masyarakat; Kesediaan masyarakat suatu daerah dapat menerima segala konsekuensi, baik konsekuensi yang bersifat positif maupun negatif terhadap didirikannya suatu perusahaan maupun toko di suatu daerah, dimana dalam hal ini merupakan suatu syarat penting.

2. Kedekatan dengan Pasar; Dekat dengan pasar akan membuat sebuah perusahaan maupun toko usaha dapat memberikan suatu tindakan pelayanan yang maksimal kepada para konsumennya dan juga mengurangi biaya distribusi.

3. Tenaga Kerja, ialah hal yang sangat mendasar dalam sebuah toko usaha. Perusahaan sebaiknya memilih dengan tepat tenaga kerja yang kompeten dan juga disiplin dalam bekerja.

4. Kedekatan dengan Bahan Mentah; Dimana jarak antara tempat atau lokasi yang ditetapkan menjadi sebuah lokasi usaha dengan lokasi bahan mentah tidak membutuhkan waktu yang sangat lama.

5. Fasilitas dan Biaya Transportasi; Tersedianya fasilitas memadai untuk mempermudah suatu penawaran dan penyaluran barang, biaya transportasi yang ringan dapat menghemat pengeluaran perusahaaan dan toko usaha.

6. Sumber Daya Alam Lainnya; Hampir setiap suatu perusahaan maupun toko usaha yang membutuhkan sebuah tenaga yangdibangkitkan dari aliran listrik, air dan lain-lain. Maka dari itu, perlu diperhatikan tersedianya sumber daya alam yang murah dan mencukupi.

\section{Manajemen Pemasaran Syariah}

Manajemen Pemasaran Syariah ialah suatu disiplin bisnis strategi yang mengarah pada proses penciptaan, penawaran dan perubahan nilai dari satu inisiator kepada suatu kelompok yang keseluruhan prosesnya sesuai dengan prinsip-prinsip 
Jurnal Ekonomi Syariah Darussalam

Vol I No I Agustus 2020, ISSN: 2745-8407

syariah. Artinya, manajemen pemasaran dalam seluruh proses penciptaan, penawaran dan proses perubahan nilai (value) harus sesuai dengan prinsip-prinsip muamalah yang Islami (Irawati, 2016:13).

\section{Kualitas Pelayanan Islami}

Salah satu faktor lain yang dapat mempengaruhi keputusan pembelian adalah kualitas pelayanan. Kualitas pelayanan yaitu merupakan suatu upaya dalam pemenuhan kebutuhan atau keinginan konsumen serta ketepatan saat penyampaian dalam memenuhi harapan dari konsumen. Perusahaan memberikan sebuah tindakan pelayanan yang terjangkau dan pelanggan juga sudah memperoleh kepuasan, maka tercipta adanya suatu tindakan pembelian kembali oleh konsumen maupun sebaliknya (Kotler, 2005:23).

Pelayanan Islami menurut pandangan Islam adalah pelayanan yang sudah dipraktekkan oleh Nabi Muhammad SAW. Memiliki lima karakteristik pelayanan dalam pandangan Islam yang dapat digunakan sebagai panduan, antara lain: 1) Jujur, 2) Bertanggung jawab (Al amanah), 3) Tidak menipu (Al khadzib), 4) Rendah hati (Khidmah), 5) Tidak lupa dengan akhirat

\section{Pelayanan dalam Perspektif Islam}

Islam mengajarkan bila ingin memberikan hasil usaha baik berupa barang maupun pelayanan hendaknya memberikan yang berkualitas kepada orang lain. seperti dijelaskan dalam Al-Qur'an QS. Al-Baqarah ayat 267:

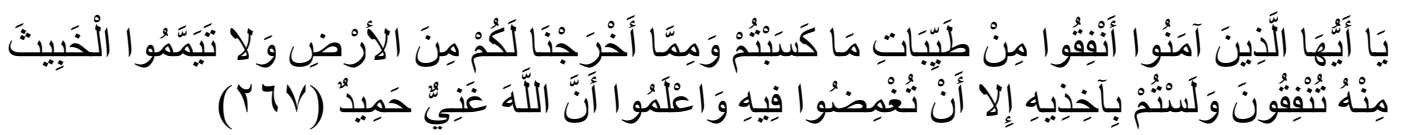

Artinya:"Hai orang-orang yang beriman, nafkahkanlah (di jalan Allah) sebagian dari hasil usahamu yang baik-baik dan sebagian dari apa yang Kami keluarkan dari bumi untuk kamu. dan janganlah kamu memilih yang buruk-buruk lalu kamu menafkahkan daripadanya, Padahal kamu sendiri tidak mau mengambilnya melainkan dengan memincingkan mata terhadapnya. Dan ketahuilah, bahwa Allah Maha Kaya lagi Maha Terpuji (Kemenag RI, 2009:20).

Ekonomi bisnis konvensional merupakan pilihan yang berdasarkan atas selera masing-masing. Manusia boleh mempertimbangkan tuntutan agama, boleh juga mengabaikan. Sedangkan dalam ekonomi Islam merupakan pilihan yang tidak 
Jurnal Ekonomi Syariah Darussalam

Vol I No I Agustus 2020, ISSN: 2745-8407

dapat dilakukan semaunya saja, semua perilaku harus berlandaskan dari Al-Qur'an dan Hadist. Dalam mewujudkan nilai-nilai ibadah dalam bekerja yang dilakukan oleh setiap insan diperlukan adab-adab dan etika yang membingkainya, sehingga nilai-nilai luhur tersebut tidak hilang sia-sia. Di antara adab dan etika dalam bekerja dalam Islam adalah: 1) Ihsan, yakni perbuatan seseorang untuk melakukan perbuatan ma'ruf dan menahan diri dari dosa, 2) Taysir, dalam memberikan pelayanan, orang muslim juga harus memperhatinkan aspek mempermudah orang lain, 3) As-Shiddiq (jujur) (Farida, 2015:17).

\section{Konsep Pelayanan dalam Islam}

Konsep pelayanan dalam Islam adalah terwujudnya dalam suatu hubungan antara manusia jikalau mengajarkan beberapa prinsip pokok yaitu: 1) Prinsip Persamaan (Musawah), 2) Prinsip Persaudaraan (Ukhuwah), 3) Prinsip Cinta Kasih (Muhabbah), 4) Prinsip Perdamaian (Silm) 5) Prinsip Tolong-menolong (Ta'awun), 6) Prinsip Toleransi (Tasamut) (Ghulam, 2010:22).

\section{Perilaku Organisasi}

Perilaku organisasi merupakan suatu studi yang menyangkut aspek-aspek tingkah laku manusia dalam suatu organisasi atau suatu kelompok tertentu. Perilaku organisasi ini meliputi aspek yang ditimbulkan dari pengaruh organisasi terhadap manusia, serta aspek yang ditimbulkan dari pengaruh manusia terhadap aspek organisasi (Thoha, 2005:5).

\section{Keputusan Pembelian}

Keputusan pembelian di supermarket dapat terjadi secara kebiasaan atau rutinitas, pembelian karena ada kebutuhan terhadap suatu produk, dan pembelian yang terjadi secara spontan. Keputusan pembelian merupakan suatu proses dalam suatu penyelesaian masalah yang meliputi: 1) Pengenalan Masalah, 2) Pencarian Informasi, 3) Evaluasi alternatif, 4) Keputusan Membeli, 5) Perilaku Setelah Pembelian (Ma'ruf, 2005:11).

\section{Penelitian Terdahulu yang Relevan}

Yulina Isnawati (2016) dengan judul “ Analisis Pengaruh Citra Merek, Persepsi Harga dan Persepsi Kualitas Pelayanan Islami terhadap Keputusan Pembelian (Studi pada Konsumen Mobil Suzuki Ertiga PT Duta Cemerlang Motors Semarang)". Teknik dalam penelitian ini menggunakan teknik analisis Regresi 
Jurnal Ekonomi Syariah Darussalam

Vol I No I Agustus 2020, ISSN: 2745-8407

Linear Berganda yang diestimasi dengan software SPSS. Hasil penelitian ini yaitu citra merek, persepsi harga dan persepsi kualitas produk mempunyai pengaruh positif terhadap keputusan pembelian. Variabel persepsi kualitas produk berpengaruh paling besar dan variabel citra merek berpengaruh paling kecil. Perbedaannya terdapat pada variabel dimana disini hanya pada Variabel citra merek (X1), persepsi harga (X2), dan terhadap keputusan pembelian(Y). Dan persamaannya terdapat pada jenis penelitiannya. Persamaanya terletak pada variabel persepsi kualitas pelayanan Islami (X3) yakni sama membahas tentang kualitas pelayanan islami.

Penelitian yang dilakukan oleh M.Ainun Nafis dari Fakultas Syariah IAIN Walisongo Semarang pada tahun 2018 dengan judul "Pengaruh Pelayanan Islami Karyawan terhadap Keputusan Menabung Nasabah dengan Akad Syariah (Study Kasus Bmt Mitra Muamalat Kota Kudus)”. Hasil penelitian yang diolah dengan program SPSS versi 18.00 for windows menunjukkan bahwa pelayanan Islami karyawan yang dilakukan di BMT Mitra Muamalat telah dilakukan dengan baik. Kemudian di uji dengan statistik menunjukkan bahwa variabel independen (pelayanan islami karyawan) terhadap variabel dependen (keputusan menabung nasabah dengan akad syariah) adalah signifikan. Ini ditunjukkan dengan lebih besarnya nilai $t$ hitung dengan $t$ tabel $(10,335>1,986)$. Besarnya pengaruh yang dapat dinotasikan adalah 537 artinya variabel keputusan menabung nasabah dapat dijelaskan oleh variabel pelayanan Islami karyawan dengan nilai sebesar 53,7\% dan sisanya 36,3\% dipengaruhi oleh faktor lain diluar penelitian ini, sedangkan persamaan regresi sederhana yang diperoleh adalah $\mathrm{Y}=4.967+0.431 \mathrm{X}$. Perbedaan penelitian terletak pada alat analisis yang digunakan yaitu analisis regresi sederhana sedangkan peneliti menggunakan alat analisis regresi berganda, sedangkan persamaannya adalah jenis penelitian merupakan jenis penelitian kuantitatif.

\section{METODE PENELITIAN}

\section{Jenis Penelitian}

Jenis penelitian yang digunakan adalah penelitian kuantitatif yang diestimasi dengan software SPSS, guna untuk menemukan apakah ada pengaruh antara lokasi dan kualitas pelayanan Islami terhadap keputusan pembelian konsumen. Penelitian metode kuantitatif dalam penelitian ini menggunakan teori (Explanatory Riserch), 
Jurnal Ekonomi Syariah Darussalam

Vol I No I Agustus 2020, ISSN: 2745-8407

tujuannya untuk menganalisis dan mendapatkan gambaran mengenai pengaruh antara variabel lokasi (X1) dan kualitas pelayanan islami (X2) terhadap keputusan pembelian konsumen (Y).

\section{Waktu dan Tempat Penelitian}

Waktu penelitian ini dilaksanakan pada bulan Maret 2019 sampai dengan bulan Agustus 2019. Tempat penelitian dilaksanakan di Unit Toko Ausath Grosir Sembako Cabang Koppontren Ausath Dusun Blokagung Desa Tegalsari Kabupaten Banyuwangi berlokasi di Jl. Pondok Pesantren Darussalam Blokagung RT: 002 RW: 004 Karangdoro Tegalsari Banyuwangi Jawa Timur.

\section{Populasi dan Sampel Penelitian}

Populasi penelitian ini adalah berjumlah 1.965 konsumen tetap Unit Toko Grosir Sembako Cabang Koppontren Ausath. Pengambilan sampel penelitian ini menggunakan jenis probability sampling dengan teknik Simple Random Sampling, maka jumlah anggota sampel minimal 10 kali dari jumlah variabel yang diteliti, yaitu 10 x 3 variabel penelitian, yakni berjumlah 30 konsumen tetap. Jadi, jumlah sampel yang diambil dalam penelitian ini adalah berjumlah 30 konsumen tetap Unit Toko Ausath Grosir Sembako Cabang Koppontren Ausath Dusun Blokagung Desa Tegalsari Kabupaten Banyuwangi.

\section{Jenis dan Sumber Data}

Data ialah fakta dana angka yang bisa dijadikan bahan untuk menyusun informasi. Dalam penelitian ini menggunakan data primer dan data sekunder, sedangkab sumber data yang digunakan dalam melakukan penelitian ini adalah dengan memakai sumber data primer, yakni data tersebut didapatkan dari hasil penyebaran kuesioner yang telah dibagikan pada responden. Responden dalam penelitian ini yaitu konsumen tetap Unit Toko Grosir Cabang Koppontren Ausath Dusun Blokagung Desa Tegalsari Kabupaten Banyuwangi. Selain itu penelitian ini juga memakai data sekunder untuk menggali data dari dokumen-dokumen, jurnal, buku, penelitian terdahulu.

\section{Teknik Pengumpulan Data}


Jurnal Ekonomi Syariah Darussalam

Vol I No I Agustus 2020, ISSN: 2745-8407

Untuk mengumpulkan data tentang keputusan pembelian konsumen pada penelitian ini, maka teknik yang digunakan dalam penelitian ini adalah: Metode observasi, metode wawancara, metode kuesioner atau angket dan metode dokumentasi.

\section{Teknik Analisi Data}

Teknik analisis data dilakukan setelah data dari seluruh responden atau sumber data lain terkumpul. Setelah data terkumpul, maka langkah selanjutnya adalah menguji validitas dan reliabilitas instrumen penelitian yang berupa pertanyaan dalam kuesioner. Setelah itu, dilanjutkan dengan menggunakan uji regresi linier berganda. Analisis regresi ganda merupakan pengembangan dari analisis regresi sederhana. Kegunaannya yaitu untuk meramalkan nilai variabel terikat (Y) apabila variabel bebas minimal dua atau lebih.

\section{HASIL PENELITIAN DAN PEMBAHASAN}

\section{Uji Validitas}

Validitas adalah sebuah ukuran yang menunjukkan tingkat ketepatan suatu alat ukur. Untuk menguji validitas, terlebih dahulu harus mencari harga korelasi antara komponen-komponen dari alat ukur secara keseluruhan dengan cara mengkorelasikan setiap butir alat ukur dengan skor total yang merupakan jumlah tiap skor butir, dengan rumus Pearson Product Moment (Ridwan, 2004:109) sebagai berikut:

$$
\begin{aligned}
& \text { rhitung } \quad=\frac{n\left(\sum X Y\right)-\left(\sum X\right)\left(\sum Y\right)}{\sqrt{\left[n \cdot \sum x^{2}-\left(\sum x\right)^{2}\right\} \cdot\left\{n \cdot \sum y^{2}-\left(\sum y\right)^{2}\right\}}} \text { Dimana: } \\
& \text { rhitung }=\text { koefisien korelasi } \\
& \Sigma_{\mathrm{Xi}}=\text { jumlah skor item } \\
& \Sigma_{\mathrm{Yi}} \quad=\text { jumlah skor total (seluruh item) } \\
& \mathrm{n} \quad=\text { jumlah responden }
\end{aligned}
$$

Untuk menentukan validitasnya dengan uji-t dengan menggunakan rumus:

$$
\begin{aligned}
& \text { thitung }=\frac{r \sqrt{n-2}}{\sqrt{1-r^{2}}} \text { Dimana: } \\
& \mathrm{t}=\text { nilai thitung }
\end{aligned}
$$


Jurnal Ekonomi Syariah Darussalam

Vol I No I Agustus 2020, ISSN: 2745-8407

$\mathrm{r} \quad=$ koefisien korelasi hasil rhitung

$\mathrm{n}=$ jumlah responden

Distribusi (tabel t) untuk $\alpha=0,05$ dan derajat kebebasan $(\mathrm{dk}=\mathrm{n} 2)$

Kaidah keputusan (Riduwan, 2004:109):

Jika thitung $>$ ttabel berarti valid, sebaliknya thitung $<$ tabel berarti tidak valid

Jika instrumen itu valid, maka dilihat dengan kriteria penafsiran mengenai indeks korelasinya (r) (Arikunto, 2013:22):

Apabila diperoleh angka yang negatif, maka korelasinya negatif. Artinya adanya kebalikan urutan. Adapun indeks korelasi pernah lebih dari 1,00.

Tabel 1 Uji Validitas Lokasi (X1)

\begin{tabular}{|c|c|l|l|l|}
\hline $\begin{array}{c}\text { No. Item } \\
\text { Pertanyaan }\end{array}$ & $\begin{array}{c}\text { Koefisien Korelasi } \\
\text { Rhitung }\end{array}$ & $\begin{array}{c}\text { Harga } \\
\text { thitung }\end{array}$ & $\begin{array}{c}\text { Harga } \\
\text { tabel }\end{array}$ & $\begin{array}{c}\text { Keput } \\
\text { usan }\end{array}$ \\
\hline 1 & 0,521 & 3,784 & 2,052 & Valid \\
\hline 2 & 0,761 & 9,568 & 2,052 & Valid \\
\hline 3 & 0,549 & 4,158 & 2,052 & Valid \\
\hline 4 & 0,556 & 4,259 & 2,052 & Valid \\
\hline 5 & 0,732 & 8,345 & 2,052 & Valid \\
\hline 6 & 0,733 & 8,382 & 2,052 & Valid \\
\hline 7 & 0,598 & 4,926 & 2,052 & Valid \\
\hline 8 & 0,771 & 10,060 & 2,052 & Valid \\
\hline 9 & 0,664 & 6,284 & 2,052 & Valid \\
\hline 10 & 0,711 & 7,609 & 2,052 & Valid \\
\hline
\end{tabular}

Sumber: Data Primer Diolah. 2019

Tabel 2 Uji Validitas Kualitas Pelayanan (X2)

\begin{tabular}{|c|c|l|l|l|}
\hline $\begin{array}{c}\text { No. Item } \\
\text { pertanyaan }\end{array}$ & $\begin{array}{c}\text { Koefisien Korelasi } \\
\text { Rhitung }\end{array}$ & $\begin{array}{c}\text { Harga } \\
\text { thitung }\end{array}$ & $\begin{array}{c}\text { Harga } \\
\text { ttabel }\end{array}$ & Keputusan \\
\hline 1 & 0,734 & 2,251 & 2,052 & Valid \\
\hline 2 & 0,739 & 2,303 & 2,052 & Valid \\
\hline 3 & 0,578 & 4,593 & 2,052 & Valid \\
\hline 4 & 0,503 & 3,563 & 2,052 & Valid \\
\hline 5 & 0,645 & 5,844 & 2,052 & Valid \\
\hline 6 & 0,703 & 7,355 & 2,052 & Valid \\
\hline 7 & 0,555 & 4,244 & 2,052 & Valid \\
\hline 8 & 0,511 & 3,660 & 2,052 & Valid \\
\hline 9 & 0,667 & 6,358 & 2,052 & Valid \\
\hline 10 & 0,675 & 6,561 & 2,052 & Valid \\
\hline
\end{tabular}

Sumber: Data Primer Diolah. 2019

Tabel 3 Uji Validitas Keputusan Pembelian (Y)

\begin{tabular}{|c|c|c|c|c|}
\hline No. Item & Koefisien Korelasi Rhitung & Harga thitung & Harga ttabel & Keputusan \\
\hline 1 & 0,639 & 5,715 & 2,052 & Valid \\
\hline 2 & 0,640 & 5,736 & 2,052 & Valid \\
\hline
\end{tabular}


Jurnal Ekonomi Syariah Darussalam

Vol I No I Agustus 2020, ISSN: 2745-8407

\begin{tabular}{|c|c|c|c|c|}
\hline 3 & 0,552 & 4,201 & 2,052 & Valid \\
\hline 4 & 0,719 & 7,876 & 2,052 & Valid \\
\hline 5 & 0,586 & 4,723 & 2,052 & Valid \\
\hline 6 & 0,685 & 6,829 & 2,052 & Valid \\
\hline 7 & 0,670 & 6,433 & 2,052 & Valid \\
\hline 8 & 0,714 & 7,707 & 2,052 & Valid \\
\hline 9 & 0,611 & 5,159 & 2,052 & Valid \\
\hline 10 & 0,661 & 6,212 & 2,052 & Valid \\
\hline
\end{tabular}

Sumber: Data Primer Diolah. 2019

Dari hasil tabel 1, 2 dan 3 uji validitas instrumen diatas penelitian diperoleh kesimpulan bahwa dari masing-masing 10 item pertanyaan dari variabel lokasi (X1), kualitas pelayanan islami (X2) dan keputusan pembelian konsumen (Y) dinyatakan valid.

\section{Uji Reliabilitas}

Mencari rtabel apabila diketahui signifikansi untuk $\alpha=0,05$ dan $\mathrm{dk}=30-2=28$, Dengan uji dua pihak, maka diperoleh $\mathrm{rtabel}=0,361$ Membuat keputusan dengan membandingkan rhitung dengan tabel Kaidah keputusan: rhitung $>$ rtabel berarti reliabel dan rhitung $<$ rtabel berarti tidak reliabel

Tabel 4 Uji Reliabilitas Lokasi (X1)

\begin{tabular}{|c|c|c|c|c|}
\hline No. item & Koefisien Korelasi & Harga thitung & Harga ttabel & Keputusan \\
\hline 1 & 0,521 & 0,685 & 0,361 & Reliabel \\
\hline 2 & 0,761 & 0,864 & 0,361 & Reliabel \\
\hline 3 & 0,549 & 0,709 & 0,361 & Reliabel \\
\hline 4 & 0,556 & 0,715 & 0,361 & Reliabel \\
\hline 5 & 0,732 & 0,845 & 0,361 & Reliabel \\
\hline 6 & 0,733 & 0,846 & 0,361 & Reliabel \\
\hline 7 & 0,598 & 0,748 & 0,361 & Reliabel \\
\hline 8 & 0,771 & 0,871 & 0,361 & Reliabel \\
\hline 9 & 0,664 & 0,798 & 0,361 & Reliabel \\
\hline 10 & 0,711 & 0,831 & 0,361 & Reliabel \\
\hline
\end{tabular}

Sumber: Data Primer Diolah. 2019

Tabel 5 Uji Reliabilitas Kualitas Pelayanan (X2)

\begin{tabular}{|c|c|c|c|c|}
\hline No. Item & Koefisien Korelasi rhitung & Harga thitung & Harga ttabel & Keputusan \\
\hline 1 & 0,734 & 0,847 & 0,361 & Reliabel \\
\hline 2 & 0,739 & 0,850 & 0,361 & Reliabel \\
\hline 3 & 0,578 & 0,722 & 0,361 & Reliabel \\
\hline 4 & 0,503 & 0,669 & 0,361 & Reliabel \\
\hline 5 & 0,645 & 0,784 & 0,361 & Reliabel \\
\hline 6 & 0,703 & 0,826 & 0,361 & Reliabel \\
\hline 7 & 0,555 & 0,714 & 0,361 & Reliabel \\
\hline 8 & 0,511 & 0,676 & 0,361 & Reliabel \\
\hline
\end{tabular}


Jurnal Ekonomi Syariah Darussalam

Vol I No I Agustus 2020, ISSN: 2745-8407

\begin{tabular}{|c|c|c|c|c|}
\hline 9 & 0,667 & 0,800 & 0,361 & Reliabel \\
\hline 10 & 0,675 & 0,806 & 0,361 & Reliabel \\
\hline
\end{tabular}

Sumber: Data Primer Diolah. 2019

Tabel 6 Uji Reliabilitas Keputusan Pembelian (Y)

\begin{tabular}{|c|c|c|c|c|}
\hline No. Item & Koefisien Korelasi rhitung & Harga thitung & Harga ttabel & Keputusan \\
\hline 1 & 0,639 & 0,780 & 0,361 & Reliabel \\
\hline 2 & 0,640 & 0,780 & 0,361 & Reliabel \\
\hline 3 & 0,552 & 0,711 & 0,361 & Reliabel \\
\hline 4 & 0,719 & 0,837 & 0,361 & Reliabel \\
\hline 5 & 0,586 & 0,751 & 0,361 & Reliabel \\
\hline 6 & 0,685 & 0,813 & 0,361 & Reliabel \\
\hline 7 & 0,670 & 0,802 & 0,361 & Reliabel \\
\hline 8 & 0,714 & 0,833 & 0,361 & Reliabel \\
\hline 9 & 0,611 & 0,759 & 0,361 & Reliabel \\
\hline 10 & 0,661 & 0,796 & 0,361 & Reliabel \\
\hline
\end{tabular}

Sumber: Data Primer Diolah. 2019

Berdasarkan tabel 4, 5 dan 6 dari hasil uji reliabilitas instrument penelitian diperoleh kesimpulan bahwa masing-masing 10 item pernyataan dari variabel lokasi (X1), kualitas pelayanan Islami (X2), dan keputusan pembelian konsumen (Y) dinyatakan Reliabel.

\section{Hasil Menggunakan SPSS}

Uji reliabilitas adalah pengujian guna mengetahui sejauh mana hasil suatu proses pengukuran dapat dipercaya. Suatu hasil pengukuran dapat dikatakan reliabel jika alat pengukuran tersebut dapat dipercaya, sehingga mendapatkan hasil yang tetap dan konsisten. Hasil pengujian reliabilitas dapat dilihat pada tabel berikut (Azwar, 2014:7):

Tabel 7 Uji Reliabilitas

\begin{tabular}{|c|c|c|c|}
\hline Variabel & Nilai r hitung & N of Items & Keterangan \\
\hline Lokasi (X1) & 0,857 & 10 & Reliabel \\
\hline Kualitas & 0,810 & 10 & Reliabel \\
\hline Pelayanan Islamii (X2) & & & \\
\hline Keputusan Pembelian (Y) & 0,842 & 10 & Reliabel \\
\hline
\end{tabular}

Sumber: Data SPSS. 2019

Berdasarkan dari Tabel 7 dapat diketahui bahwasannya koefisien reliabilitas instrument variabel lokasi (X1) sebesar 0,857, variabel kualitas pelayanan Islamii (X2) sebesar 0,810 dan variabel keputusan pembelian (Y) sebesar 
Jurnal Ekonomi Syariah Darussalam

Vol I No I Agustus 2020, ISSN: 2745-8407

0,842. Dapat diketahui bahwa $r$ hitung lebih besar daripada $r$ tabel $(0,6)$, maka dari ketiga variabel tersebut dinyatakan reliabel.

\section{Uji Normalitas}

Uji normalitas bertujuan untuk menguji apakah data yang digunakan dalam model regresi berdistribusi normal atau tidak. Uji normalitas juga bisa menggunakan uji One-Sample Kolmogorow-Smirnow. Uji ini dilakukan dengan membandingkan nilai probabilitas distribusi teoritik dari jenis distribusi probabilitas yang diasumsikan terhadap distribusi empirik. Selisih maksimum keduanya disebut dengan Dmax. Nilai Dmax lalu dibandingkan dengan nilai kritis Kolmogorov-Smirnov untuk menentukan keputusan apakah satu set data mengikuti distibusi yang diasumsikan atau tidak. Dasar pengambilan keputusan normal atau tidaknya data yang diolah adalah Asymp. Sig. (2-tailed) > 0,05 (Ghozali, 2011:160).

Berdasarkan hasil perhitungan uji Normalitas menunjukkan bahwa variabel X1 adalah 0,058, variabel X2 adalah 0,133, dan variabel $\mathrm{Y}$ adalah 0,200. Jika dibandingkan dengan taraf Normalitas sebesar $(0,05)$ maka variabel $\mathrm{X} 1$, X2, dan $\mathrm{Y}$ berdistribusi Normal. Hal ini dapat dibuktikan dengan nilai dari X1 $(0,058>0.05)$, X2 $(0,133>0,05)$ dan Y $(0,200>0,05)$.

Hasil penelitian telah dipaparkan pada BAB sebelumnya, agar hasil penelitian tersebut dapat digunakan sebagai hasil temuan, maka pada BAB ini akan diuraikan dengan berpedoman pada teori-teori yang relevan yang telah dilakukan oleh peneliti-peneliti terdahulu. Penelitian yang dilaksanakan di Unit toko Ausath Grosir Sembako cabang Koppontren Ausath Dusun Blokagung Desa Karangdoro Kecamatan Tegalsari Kabupaten Banyuwangi dengan menggunakan pendekatan metode penelitian kuantitatif. Metode ini dapat diartikan sebagai metode penelitian yang berdasarkan pada filsafat positifisme, dari judul penelitian pengaruh lokasi dan kualitas pelayanan Islami terhadap keputusan pembelian konsumen di Unit Toko Ausath Grosir Sembako cabang koppontren Ausath Dusun Blokagung Desa Karangdoro Kecamatan Tegalsari Kabupaten Banyuwangi.

Hal ini didukung oleh hasil penelitian terdahulu M. Wahab Khasbulloh (2016) yaitu terdapat pengaruh Analisis Pengaruh Kualitas Pelayanan Islami Dan Profit And Loss Sharing Terhadap Keputusan Menabung Di Bank Pembiayaan Rakyat Syariah (BPRS) Suriyah Cabang Semarang. Tujuan diadakannya penelitian ini 
Jurnal Ekonomi Syariah Darussalam

Vol I No I Agustus 2020, ISSN: 2745-8407

adalah untuk mengetahui ada tidaknya pengaruh positif dan signifikan antara variabel lokasi (X1) dan variabel kualitas pelayanan Islami (X2) terhadap variabel keputusan pembelian konsumen (Y) di Unit Toko Ausath Grosir Sembako Cabang Koppontren Ausath Dusun Blokagung Desa Tegalsari Kabupaten Banyuwangi. Data diperoleh dari sumber asli atau konsumen yang menjadi pelanggan, yakni hasil dari jawaban angket atau kuesioner dari responden yaitu konsumen tetap yang ada di Unit Toko Ausath Grosir Sembako Cabang Koppontren Ausath Dusun Blokagung Desa Tegalsari Kabupaten Banyuwangi. Jumlah konsumen yang menjadi pelanggan di Unit Toko Ausath Grosir Sembako Cabang Koppontren Ausath Blokagung Banyuwangi adalah berjumlah 1.965 konsumen, akan tetapi penelitian ini mengambil sampel yang sebesar 30 responden, guna untuk mengisi angket yang disediakan dalam penelitian ini, kemudian data tersebut dianalisa dengan menggunakan statistik regresi berganda.

Adapun data yang berkaitan dengan jenis kelamin responden konsumen, yang dijadikan sampel pada penelitian ini adalah 42\% perempuan dan 58\% laki-laki. Perbedaan ini diakibatkan karena dalam pembelian yang bentuknya grosiran, lebih memicu pada laki-laki, dikarenakan jumlah volume yang sangat banyak dibeli dalam setiap harinya. Oleh karena itu, kebanyakan jumlah responden sampel yang lebih dominan adalah kaum adam. Kegiatan dalam analisis data adalah mengelompokkan data berdasarkan variabel dan jenis responden, menyajikan data tiap variabel yang diteliti, melakukan perhitungan untuk menjawab rumusan masalah, kemudian melakukan perhitungan untuk menguji hipotesis yang telah diajukan. Teknik pengumpulan data yang digunakan dalam penelitian ini adalah menggunakan teknik dokumentasi dan angket atau kuesioner. Kuesioner adalah terdiri dari berbagai daftar pertanyaan atau pernyataan yang harus dijawab oleh responden. Teknik ini merupakan suatu bentuk alat atau instrumen pengumpulan data dalam bentuk pertanyaan atau pernyataan yang disusun berdasarkan dengan pokok materi yang berhubungan dengan penelitian yang diteliti. Adapun jumlah item dalam kuesioner ini adalah 30 item pernyataan dari jumlah 3 variabel.

Penelitian dalam bab III angket yang telah diteliti sudah valid reliabel dan normal, kemudian data yang telah dianalisis dapat diterapkan di Unit toko Ausath Grosir Sembako cabang koppontren Ausath Dusun Blokagung Desa Karangdoro 
Jurnal Ekonomi Syariah Darussalam

Vol I No I Agustus 2020, ISSN: 2745-8407

Kecamatan Tegalsari Kabupaten Banyuwangi, berdasarkan analisis yang telah dilakukan adalah sebagai berikut:

1. Variabel lokasi (X1) berpengaruh signifikan terhadap keputusan pembelian konsumen (Y) di Unit toko Ausath Grosir Sembako cabang Koppontren Ausath Dusun Blokagung Desa Karangdoro Kecamatan Tegalsari Kabupaten Banyuwangi; Hasil penelitian ini, terdapat pengaruh antara variabel lokasi (X1) terhadap keputusan pembelian (Y). Hasil analisis bahwa variabel lokasi diperoleh nilai thitung $=2,671$ dan probabilitas sebesar 0,003. Jika dibandingkan dengan tabel 2,052 maka thitung 2,671 > tabel 2,052 dan $\rho 0,003<0,05$. Hal ini menunjukan bahwa Ha diterima, artinya lokasi (X1) berpengaruh positif terhadap keputusan pembelian konsumen (Y) di Toko Ausath Grosir Sembako Cabang Koppontren Ausath Dusun Blokagung Desa Tegalsari Kabupaten Banyuwangi. Hasil penelitian menunjukkan bahwa Ha diterima, artinya variabel lokasi (X1) di Unit Toko Ausath Grosir Sembako cabang Koppontren Ausath sudah dikatakan baik yang membuat Toko Ausath Grosir Sembako terus maju dan berkembang. Salah satu faktor yang membuat Toko Ausath Grosir Sembako cabang Koppontren Ausath dikenal dan banyak konsumen adalah dengan lokasi yang strategis terletak di jalan utama yang ramai, yakni dekat depan pintu gerbang utama pondok pesantren putra Darussalam Blokagung Tegalsari Banyuwangi yang berjumlah sekitar 6000 santri. Toko Ausath Grosir Sembako ini sudah cukup efisien dalam memilih lokasi untuk membuka usaha. Hal ini sangat tepat dan efesien dalam mendapatkan konsumen dalam jumlah yang banyak, untuk melakukan pembelian di Unit Toko Ausath Grosir Sembako.

2. Variabel kualitas pelayanan Islami (X2) berpengaruh signifikan terhadap keputusan pembelian konsumen (Y) di Unit toko Ausath Grosir Sembako cabang Koppontren Ausath Dusun Blokagung Desa Karangdoro Kecamatan Tegalsari Kabupaten Banyuwangi; Hasil penelitian ini, menunjukkan bahwa terdapat pengaruh signifikan antara variabel kualitas pelayanan Islami (X2) terhadap variabel keputusan pembelian konsumen (Y). Dibuktikan dengan hasil variabel kualitas pelayanan Islami (X2) diperoleh nilai thitung sebesar 2,495 dan probabilitas sebesar 0,001. Jika dibandingkan dengan tabel 2,052 maka 
Jurnal Ekonomi Syariah Darussalam

Vol I No I Agustus 2020, ISSN: 2745-8407

thitung 2,495 $>$ tabel 2,052 dan $\rho 0,001<0,05$. Maka Ha diterima. Hasil penelitian menunjukkan bahwa Ha diterima, artinya variabel kualitas pelayanan Islami (X2) Yang digunakan di Unit Toko Ausath Grosir Sembako sudah dikatakan baik yang membuat Toko Ausath Grosir Sembako terus maju dan berkembang. Salah satu variabel yang membuat Toko Ausath Grosir Sembako dikenal dan banyak konsumen adalah dengan variabel pelayanan yang menerapkan prinsipprinsip Islam. Toko Ausath Grosir Sembako ini sudah cukup efisien dalam menerapkan pelayanan Islami. Hasil wawancara pada salah satu karyawan Toko Ausath Grosir Sembako yakni bapak Hamam, yang menuturkan bahwa Toko Ausath Grosir Sembako dalam hal pelayanannya adalah sesuai dengan prinsip Islami. Hal ini sangat tepat dan efesien dalam mendapatkan konsumen dalam jumlah yang banyak. Pelayanan yang baik dalam perspektif Islam harus selalu ditingkatkan lagi agar dalam persaingan sekarang ini Toko Ausath Grosir Sembako masih tetap menjadi toko yang maju dan amanah.

3. Variabel lokasi (X1) dan kualitas pelayanan Islami (X2) berpengaruh Signifikan secara simultan atau bersama-sama terhadap variabel keputusan pembelian konsumen (Y) di Unit toko Ausath Grosir Sembako cabang koppontren Ausath Dusun Blokagung Desa Karangdoro Kecamatan Tegalsari Kabupaten Banyuwangi; Uji hipotesis secara bersama-sama atau simultan dinotasikan dalam uji F yang menyatakan bahwa terdapat pengaruh signifikan secara simultan antara variabel lokasi (X1) dan kualitas pelayanan Islami (X2) terhadap variabel dependen yaitu keputusan pembeliana konsumen (Y) di Unit toko Ausath Grosir Sembako cabang koppontren Ausath Dusun Blokagung Desa Tegalsari Kabupaten Banyuwangi dengan diperoleh nilai Fhitung = 32,066 dan probabilitas sebesar 0,000. Jika dibandingkan dengan $F_{\text {tabel }}$ 3,35 maka Fhitung 13,066 $>$ Ftabel 3,35 dan $\rho 0,000<0,05$ sehingga dapat disimpulkan bahwa variabel independen lokasi (X2) dan kualitas pelayanan Islami (X2) mempengaruhi variabel dependen keputusan pembelian konsumen secara signifikan atau hipotesis diterima. Berdasarkan Tabel $R$ Square sebesar 0, 491 atau $49,10 \%$ yang artinya hubungan antara X1, X2 dan Y dapat dijelaskan sebesar 49,10\%. Hubungan ini akan sempurna (100\%) atau mendekati apabila ada variabel independent lain dimasukkan ke dalam model. Dengan kata lain, 
Jurnal Ekonomi Syariah Darussalam

Vol I No I Agustus 2020, ISSN: 2745-8407

variabel lokasi (X1) dan kualitas pelayanan Islami (X2) memberi pengaruh bersama sekitar 49,10\% terhadap keputusan pembelian konsumen (Y) di Toko Ausath Grosir Sembako. Sedangkan untuk sisanya yaitu sebesar 50,90\% dipengaruhi oleh variabel-variabel lainnya yang tidak diteliti dalam penelitian ini. Maka dapat disimpulkan bahwa variabel lokasi (X1) dan variabel kualitas pelayanan Islami (X2) tidak dominan dalam memberikan pengaruh terhadap variabel keputusan pembelian konsumen (Y) di Unit toko Ausath Grosir Sembako cabang koppontren Ausath Dusun Blokagung Desa Tegalsari Kabupaten Banyuwangi. Artinya pengaruh variabel lokasi (X1) dan variabel kualitas pelayanan Islami (X2) dikategorikan lemah dalam mempengaruhi variabel keputusan pembelian konsumen (Y) di Unit toko Ausath Grosir Sembako cabang koppontren Ausath Dusun Blokagung Desa Tegalsari Kabupaten Banyuwangi.

\section{E. KESIMPULAN}

Permasalahan telah dikaji secara teoritis dalam BAB II, metode penelitian dibahas dalam BAB III, dan hasil penelitian secara hipotesis dijelaskan dalam BAB IV, dan pembahasan BAB V, maka dalam BAB IV ini dapat diambil kesimpulan. Setelah proses mulai dari menentukan judul, kemudian mendapat referensireferensi buku pendukung sampai dengan mengadakan survey dan melaksanakan penelitian dengan cara menyebarkan angket atau kuesioner kepada konsumen dan kemudian menganalisis data dari hasil penelitian maka disimpulkan sebagai berikut:

1. Berdasarkan rumusan masalah yang pertama menghasilkan bahwa terdapat pengaruh signifikan antara variabel lokasi (X1) terhadap variabel keputusan pembelian konsumen (Y) di Unit toko Ausath Grosir Sembako cabang koppontren Ausath Dusun Blokagung Desa Karangdoro Kecamatan Tegalsari Kabupaten Banyuwangi. Pemilihan lokasi yang tepat dan strategis, yakni tepat berada di depan gerbang utama Pondok Pesantren Darussalam Putra, maka akan semakin banyak pula masyarakat yang berminat untuk menjadi konsumen di Unit toko Ausath Grosir Sembako cabang koppontren Ausath Dusun Blokagung Desa Karangdoro Kecamatan Tegalsari Kabupaten Banyuwangi. 
Jurnal Ekonomi Syariah Darussalam

Vol I No I Agustus 2020, ISSN: 2745-8407

2. Berdasarkan rumusan masalah yang kedua menghasilkan bahwa terdapat pengaruh signifikan antara variabel kualitas pelayanan Islami (X2) terhadap variabel keputusan pembelian konsumen (Y) di Unit toko Ausath Grosir Sembako cabang koppontren Ausath Dusun Blokagung Desa Karangdoro Kecamatan Tegalsari Kabupaten Banyuwangi. Hasil dari penelitian ini menunjukkan bahwa dengan menerapkan variabel kualitas pelayanan Islami (X2) dapat mempengaruhi masyarakat untuk tetap menjadi konsumen yang setia membeli di Unit toko Ausath Grosir Sembako cabang koppontren Ausath Dusun Blokagung Desa Karangdoro Kecamatan Tegalsari Kabupaten Banyuwangi, hal ini dikarenakan pelayanan dengan prinsip Islam merupakan salah satu kewajiban bagi setiap umat Islam, sehingga dengan pelayanan yang Islami juga akan memberikan manfaat dan nilai keberkahan kepada masyarakat khususnya yang akan menjadi konsumen di Unit toko Ausath Grosir Sembako cabang koppontren Ausath Dusun Blokagung Desa Karangdoro Kecamatan Tegalsari Kabupaten Banyuwangi.

3. Terdapat pengaruh signifikan secara simultan antara variabel lokasi (X1) dan variabel kualitas pelayanan Islami (X2) terhadap variabel keputusan pembelian konsumen (Y) di Unit toko Ausath Grosir Sembako cabang koppontren Ausath Dusun Blokagung Desa Karangdoro Kecamatan Tegalsari Kabupaten Banyuwangi. Hal ini dapat dilihat dari perkembangan konsumen dalam setiap harinya, dengan semakin meningkatnya jumlah persentase yakni sebesar 20\% jumlah satuan pertambahan setiap konsumen yang memutuskan dengan dua kategori, yang pertama yakni untuk sekedar mampir hanya melihat atau memilih untuk meneruskan melakukan pembelian di Unit toko Ausath Grosir Sembako cabang koppontren Ausath Dusun Blokagung Desa Karangdoro Kecamatan Tegalsari Kabupaten Banyuwangi.

\section{DAFTAR PUSTAKA}

Al Qur'an dan Terjemahnya. 2009. Departemen Agama RI.

Afifuddin. 2016. Pengaruh Lokasi, Promosi dan Harga Terhadap Kepuasan Konsumen Di Wisata Bahari Lamongan. ejournal.steisia.ac.id

Al Arif, M Nur Rianto. 2010. Lembaga Dasar-Dasar Pemasaran Bank Syariah. Bandung: Edisi Alfabeta.

Antoni, Ahmad. 2003. Kamus Lengkap Ekonomi. Jakarta: Gitamedia Press. 
Jurnal Ekonomi Syariah Darussalam

Vol I No I Agustus 2020, ISSN: 2745-8407

Assauri, Sofjan. 2004. Manajemen Pemasaran. Edisi II. Jakarta: Rajawali Press. Azwar, Saifuddin. 2014. Reabilitas dan Validitas. Yogyakarta: Pustaka Pelajar.

Farida, Lu'luul. 2015. Pengaruh Pelayanan dan Keunggulan Produk Tabungan Faedah Terhadap Kepuasan Nasabah di BRI Syariah Kantor cabang Pembantu Genteng Banyuwangi. Penelitian. IAI Darussalam Blokagung.

Ghulam, Ahmad Syaiful. 2010. Strategi Pelayanan Pegadaian Syariah di Sidoarjo. Penelitian. Institut Agam Islam Negeri Sunan Ampel Surabaya.

Hadi, Sutrisno. 2001. Meotodologi Reaserch Jilid III. Yogyakarta: Andi Offset.

Hariyati, Ratih. 2005. Bauran Pemasaran dan Loyalitas Konsumen. Bandung: Edisi Alfabeta.

Irawati, Elly Mery. 2016. Pengaruh Penerapan Karakteristik Marketing Syariah Terhadap Kepuasan Nasabah pada Bank Syariah Sragen. Penelitian. Fakultas Ekonomika dan Bisnis IAIN Salatiga.

Isnawati, Yulina. 2018. Analisis Pengaruh Citra Merek, Persepsi Harga dan Persepsi Kualitas Pelayanan Islami Terhadap Keputusan Pembelian (Studi pada Konsumen Mobil suzuki Ertiga PT. Duta Cemerlang Motors Semarang). Penelitian. Fakultas Ekonomika dan Bisnis Universitas Diponegoro.

Karim, Adiwarman A. 2014. Bank Islam (Analisis Fiqh dan Keuangan). Jakarta: PT. Raja Grafindo.

Kertajaya, Hermawan dan Syakir Sula, Muhammad. 2006. Syariah Marketing. Bandung: Mizan Pustaka.

Khasbulloh, Wahab. 2016. Analisis Pengaruh Pelayanan Islami dan Profit And Loss Sharing Terhadap Keputusan Menabung di Bank Pembiayaan Rakyat Syariah (BPRS) Suriyah Cabang Semarang. Penelitian. Fakultas Ekonomika dan Bisnis Universitas Diponegoro.

Khoidah, Yus. 2018. Pengaruh Kualitas Pelayanan dan Produk Terhadap Kepuasan Nasabah di BRI Syariah KCP Genteng. Penelitian. IAI Darussalam Blokagung.

Kotler dan Armstrong, G. 2008. Dasar-Dasar Pemasaran. Edisi 11. Jakarta: Penerbit Indeks.

Lupioadi. 2001. Manajemen Pemasaran Jasa. Edisi 2. Jakarta: Salemba Empat.

Luthans, Fred. 2009. Perilaku Organisasi. Yogyakarta: Penerbit ANDI.

Marwan Asri, 2000. Marketing. Yogyakarta: UPP-AMP YKNPN.

Nafis, Ainun. 2015. Pelayanan Islami Karyawan Terhadap Keputusan Menabung Nasabah dengan Akad Syariah (Study Kasus BMT Mitra Muamalat Kota Kudus). Penelitian. Fakultas Syariah IAIN Walisongo Semarang.

Saputro, Rihasto Mega. 2015. Analisis Pengaruh Kualitas Produk, Harga, Kualitas Pelayanan, Dan Lokasi Terhadap Keputusan Pembelian(Studi Kasus pada Grand Panorama Resto Semarang). Penelitian. Fakultas Ekonomika dan Bisnis Universitas Diponegoro.

Surya Utami, Ida Ayu Inten. 2015. Pengaruh Kualitas Layanan Terhadap Kepuasan Pelanggan Restoran Baruna Sanur. Jurnal. Fakultas Ekonomi dan Bisnis Universitas Udayana, Bali, Indonesia. 